\title{
Simultaneous Removal of Heavy Metals And Bioelectricity Generation In Microbial Fuel Cell Coupled With Constructed Wetland: An Optimization Study On Substrate And Plant Types
}

Lu Wang ( $\square$ wangluhbl@163.com )

Anhui Polytechnic University https://orcid.org/0000-0002-7847-1465

Dayong Xu

Anhui Polytechnic University

Qingyun Zhang

Anhui Polytechnic University

Tingting Liu

Anhui Polytechnic University

Zhengkai Tao

Anhui Polytechnic University

\section{Research Article}

Keywords: CW-MFC, Heavy metal, Sludge, Bioelectricity, Substrate and plant types

Posted Date: May 27th, 2021

DOI: https://doi.org/10.21203/rs.3.rs-494707/v1

License: (a) (1) This work is licensed under a Creative Commons Attribution 4.0 International License.

Read Full License

Version of Record: A version of this preprint was published at Environmental Science and Pollution Research on August 2nd, 2021. See the published version at https://doi.org/10.1007/s11356-021-156883. 


\section{Abstract}

A microbial fuel cell coupled with constructed wetland (CW-MFC) was built to remove heavy metals (Zn and $\mathrm{Ni}$ ) from sludge. The performance for the effects of substrates (granular activated carbon (GAC), ceramsite) and plants (Iris pseudacorus, Water hyacinth) towards the heavy metal treatment as well as electricity generation were systematically investigated. The CW-MFC systems possessed higher $\mathrm{Zn}$ and Ni removal efficiencies as compared to $\mathrm{CW}$. The maximal removal rates of $\mathrm{Zn}(76.88 \%)$ and $\mathrm{Ni}(66.02 \%)$ were obtained in system CW-MFC based on GAC and Water hyacinth (GAC- and WH-CW-MFC). Correspondingly, the system produced the maximum voltage of $534.30 \mathrm{mV}$ and power density of 70.86 $\mathrm{mW} \cdot \mathrm{m}^{-3}$, respectively. Plant roots and electrodes contributed supremely to the removal of heavy metals, especially for GAC- and WH-CW-MFC systems. The coincident enrichment rates of $\mathrm{Zn}$ and Ni reached $21.10 \%$ and $26.04 \%$ for plant roots, $14.48 \%$ and $16.50 \%$ for electrodes, respectively. A majority of the heavy metals on the sludge surface were confirmed as $\mathrm{Zn}$ and Ni. Furthermore, the high-valence $\mathrm{Zn}$ and $\mathrm{Ni}$ were effectively reduced to low-valence or elemental metals. This study provides a theoretical guidance for the optimal construction of CW-MFC and the resource utilization of sludge containing heavy metals.

\section{Highlights}

a. Six lab-scaled CW-MFCs were constructed to remove $\mathrm{Zn}$ and Ni from sludge.

b. GAC and Water hyacinth boosted the heavy metal removal and bioelectricity generation.

c. High-valence Zn and Ni were effectively reduced to low-valence or elemental metals.

d. The findings may be extended to the treatment of refractory heavy metals from excess sludge.

\section{Introduction}

Biotechnology, as an efficient sewage treatment method, has been widely applied to the municipal sewage plant. However, these biological processes are reported to form large amounts of excess sludge with complicated ingredients (Ke et al. 2012). As a result, the handling and disposal of sludge requires a lot of financial and material capabilities of municipal sewage plant (Qian et al. 2016). It is therefore imperative to develop affordable and effective technologies to enable a sufficient disposal of sludge. Several strategies, including bioleaching (Chen and Cheng 2019), chemical extraction (Liu et al. 2018b), electrokinetics (Gao et al. 2013), hydrothermal carbonization (Liu et al. 2018a), etc., emerged for heavy metal removals or pathogen disinfection from sludge. The chemical utilization or complex operation of these techniques gave rise to the limitation for effective sludge treatment (Hu et al. 2021). Due to its high chemical energy, a sustainable development proposal was also put forward by utilizing sludge as renewable energy source to the land (Zhou et al. 2020). Nevertheless, the accumulation of heavy metals in the sludge generated by wastewater treatment processes caused potential risks to animals and humans through the food chain, thereby limiting the application of sludge (Shamsollahi et al. 2019, Yang 
et al. 2013). Therefore, the development of cost-effective and energy-neutral technologies is currently the most desired approach (Gupta et al. 2021).

Constructed wetlands (CWs) were designed to simulate the natural purification of pollutants by the wetland plants, substrates and microorganisms (Shen et al. 2018). CWs displayed potential applicability for the treatment of sludge containing heavy metals because of its simple technological process, low operation cost and good purification capacity (Fan et al. 2013, Zhong et al. 2020). For instance, a sludge treatment wetland with ventilation was conducted by scholar to analyze the removal and fate of heavy metals from excess sludge (Meng et al. 2020). However, the anaerobic conditions in the lower sections of CWs resulted in the slow decomposition of organic matters and lack of favorable electron acceptors (Srivastava et al. 2017). As a consequence, high concentration of sludge organics was not only underutilized in CW process, but also increased its operating load.

Microbial fuel cell (MFC), as a promising purification technology, has been applied to boost the performance for the removal of heavy metals (Xu et al. 2019). $80 \mathrm{mg} \cdot \mathrm{L}^{-1}$ of $\mathrm{Cr}(\mathrm{VI})$ was reported to be completely removed within $72 \mathrm{~h}$ and bio-electrochemically reduced to nontoxic $\mathrm{Cr}(\mathrm{III})$ in a dual chamber MFCs (Li et al. 2018). The device MFCs required anode (anaerobic) and cathode (aerobic) regions, which was highly matched with CWs (Xu et al. 2021). On this basis, an integrated CW-MFC biotechnology was of great significance for enhancing the wastewater treatment containing heavy metals (Xu et al. 2019, Zhong et al. 2020). A removal study of $\mathrm{Pb}(\mathrm{II})$ by CW-MFC displayed that the removal rate was up to $85 \%$ with a maximum power density of $7.432 \mathrm{~mW} \cdot \mathrm{m}^{-3}$ (Zhao et al. 2020). In another study, approximately $91 \%$ removal of $\mathrm{Cr}(\mathrm{VI})$ was obtained in CW-MFC under the optimal operating conditions (Mu et al. 2020).

Substrate and plant types were considered as important parameters for optimizing CW-MFCs (Di et al. 2020, Ge et al. 2020). The addition of optimal substrate to the CW-MFCs had been reported to enhance strongly the treatment of pollutants and prolong the running period (Wang et al. 2020). Plant roots were capable of removing pollutants directly from wastewater by adsorption and enrichment (Zhou et al. 2018). Meanwhile, root exudates could provide carbon and energy source for the growth of rhizosphere microorganisms (Wang et al. 2017). However, detailed information about the heavy metal removal from sludge by CW-MFCs, based on substrate and plant types, is still scarce.

Herein, six lab-scaled CW-MFCs were constructed to investigate the performance of substrate and plant types on the removal of heavy metals ( $\mathrm{Zn}$ and $\mathrm{Ni}$ ). The power generation and other electrochemical indices were determined by a paperless recorder (MIK-9600). XRD analysis was used to characterize the migration and transformation of $\mathrm{Zn}$ and $\mathrm{Ni}$ in CW-MFCs. The findings in this study will provide guidance for the optimal construction of CW-MFC and the resource utilization of sludge containing heavy metals.

\section{Materials And Methods}

2.1 CW-MFC construction and untreated sludge 
Vertical lab-scaled CW-MFC systems were built as polyacrylic plastic columns with an inner diameter of $15 \mathrm{~cm}$ and a height of $40 \mathrm{~cm}$. From the bottom upward, the device was filled up as follows: a support layer, an anode layer, a separation layer and a sludge layer. Carbon clothes incorporating stainless steel meshes were embedded into the anode and sludge layer to serve as the anode and cathode $(12 \mathrm{~cm}$ apart), respectively. The external circuit was connected to the $1000 \Omega$ resistance by the copper wire. The untreated sludge was the mixture in 1:1 (v/v) ratio of the anaerobic and industrial sludge collected from sewage treatment plant and automobile enterprise in Wuhu, Anhui, China. Detailed CW-MFC construction and the properties of the untreated sludge were described previously (Liu et al. 2020b).

\subsection{Experimental operation}

Granular activated carbon (GAC) and ceramsite (3-5 mm in diameter, respectively) were selected as fillers for the anode layer to evaluate the effect of substrate types on the performance of CW-MFC. Additionally, the emergent plant Iris pseudacorus and floating plant Water hyacinth were irrigated with tap water for one week, and then transplanted into the sludge layer to remove the heavy metals. For the purpose of this work, six CW-MFC devices were prepared and divided into two groups in this experiment. CW, the traditional constructed wetland, was set as the blank control filled with GAC. NP-CW-MFC was built with GAC in the anode layer but without any plant materials. GAC- and CER-CW-MFC were respectively filled with granular activated carbon and ceramsite in the anode layer, and planted with Water hyacinth in the sludge layer. Plant materials (Iris pseudacorus and Water hyacinth) were respectively transplanted into the CW-MFC system to prepare the IP- and WH-CW-MFC system.

At the start-up period, the anaerobic sludge collected from sedimentation tank of Zhujiaqiao Wastewater Treatment Plant (Wuhu, Anhui, China) was mixed with nutrient solution in 1:1 (v/v) ratio and subsequently inoculated into the CW-MFCs (Wang et al. 2019). The nutrient solution consisted of $\left(\mathrm{L}^{-1}\right)$ :

$\mathrm{C}_{6} \mathrm{H}_{12} \mathrm{O}_{6} 0.4717 \mathrm{~g}, \mathrm{KH}_{2} \mathrm{PO}_{4} 0.9 \mathrm{~g}, \mathrm{~K}_{2} \mathrm{HPO}_{4} \cdot 3 \mathrm{H}_{2} \mathrm{O} 0.68 \mathrm{~g}, \mathrm{NH}_{4} \mathrm{Cl} 0.1 \mathrm{~g}, \mathrm{CaCl}_{2} 0.1 \mathrm{~g}$, EDTA $0.1 \mathrm{~g}, \mathrm{MgCl}_{2} \cdot 6 \mathrm{H}_{2} \mathrm{O}$ $0.1 \mathrm{~g}, \mathrm{MnSO}_{4} \cdot \mathrm{H}_{2} \mathrm{O} 0.2 \mathrm{mg}, \mathrm{CoCl}_{2} \cdot 6 \mathrm{H}_{2} \mathrm{O} 2.4 \mathrm{mg}, \mathrm{CuCl}_{2} \cdot 2 \mathrm{H}_{2} \mathrm{O} 1 \mathrm{mg}, \mathrm{FeCl}_{2} 1 \mathrm{mg}$ and $\mathrm{ZnCl}_{2} 5 \mathrm{mg}$. After a 2week adaptation period, the untreated sludge was added into the CW-MFC systems. The COD of anode liquor was monitored at regular intervals and kept around $500 \mathrm{mg} / \mathrm{L}$ by the addition of glucose. Anolyte and sludge samples were collected in triplicate every 4 days. The concentration of heavy metals as well as physiochemical indexes, including $\mathrm{pH}$ and oxidation-reduction potential (ORP), were tested immediately after sampling. Finally, the plant and electrode were sampled for heavy metal determination. All the CW-MFCs were exposed to the room temperature of $20-30{ }^{\circ} \mathrm{C}$.

\subsection{Analytical methodology}

\subsubsection{Determination and valence analysis of heavy metals}

Sludge and plant (roots, stems and leaves) samples were dried at $105^{\circ} \mathrm{C}$ for $24 \mathrm{~h}$ and then were ground into powder. $0.2 \mathrm{~g}$ and $0.15 \mathrm{~g}$ of sieved sludge and plant were respectively digested with $10 \mathrm{~mL}$ aqua regia $\left(\mathrm{HNO}_{3} \cdot 3 \mathrm{HCl}\right), 5 \mathrm{~mL} \mathrm{HClO}$ and $2 \mathrm{~mL}$ concentrated $\mathrm{H}_{2} \mathrm{SO}_{4}$ in a PTFE tube for $24 \mathrm{~h}$. Then the digestion tubes were respectively heated at $185^{\circ} \mathrm{C}$ for $3 \mathrm{~h}$ and $205^{\circ} \mathrm{C}$ for $7 \mathrm{~h}$ by the COD rapid digestion apparatus 
(SN-102A, Sunde Environmental Protection Technology Ltd., China). The cooled digestion solution were passed through the filter membrane $(0.45 \mu \mathrm{m})$ to eliminate impurities and then diluted to $50 \mathrm{~mL}$. The sludge leachate and aqua regia soaked with electrodes also underwent such filtration and constant volume operation. Finally, the concentrations of heavy metals in digested sludge and plant samples, as well as in sludge leachate and soaking solution were determined by a flame atomic absorption spectrometer (TAS-990, Purkinje General Instrument Ltd., China) (Liu et al. 2020b). The chemical forms of the elements on the surface of sludge were characterized by X-ray photoelectron spectroscopy (XPS, AXIS NOVA, Shimadzu, Japan).

\subsubsection{Water quality determination}

COD was tested by the fast digestion spectrophotometric method (HJ/T399-2007). The pH and ORP were measured using a portable pH/ORP meter (PHB-4, Shanghai Leici).

\subsubsection{Measurement of electrical performance}

The voltage date across the external resistor was collected by a paperless recorder (MIK-9600). The current density $\left(\mathrm{l}, \mathrm{mA} / \mathrm{m}^{-3}\right)$ and power density $\left(\mathrm{P}, \mathrm{mW} / \mathrm{m}^{-3}\right)$ were calculated according to the equations $I=\frac{U}{R V}$ and $P=\frac{U^{2}}{R V}$, where $\mathrm{U}, \mathrm{R}$ and $\mathrm{V}$ indicate the voltage $(\mathrm{V})$, electric resistance $(\Omega)$ and effective working volume of anode $\left(\mathrm{m}^{3}\right)$, respectively. When the bioelectrogenesis entered the stable period, the power density and polarization curves were measured by varying the external resistance over a range of $100-10,000 \Omega$ to acquire the corresponding voltage. Then the curves were obtained by plotting the voltage or power density versus current density.

\subsection{Data analysis}

In this study, the removal rate was calculated and the curves in the figures were plotted in Origin 8.5 from the mean values of 6 batches. In addition, XPS Peak 4.1 software was used for valence analysis of heavy metals.

\section{Results And Discussion}

\subsection{Effect of substrate and plant types on $\mathrm{pH}$ and ORP}

The $\mathrm{pH}$ values of anode solution in CW-MFC systems ranged from 6.70 to 7.08 (Table 1), indicating that CW-MFCs possessed better performance in microneutral environment. It was noted that the CW-MFCs filled with GAC presented a weak acidity $(<7.0)$. Hence, CW-MFCs played a similar role in regulating the $\mathrm{pH}$ of anode area in comparison with $\mathrm{CW}$ reactor, especially for systems based on GAC.

ORP reflected the macroscopic oxidation-reduction behavior of all substances in aqueous solution. It was considered as the crucial parameter to monitor the anode anaerobism and cathode aerobism, which 
affected the pollutant removal and energy recovery in the CW-MFC (Doherty et al. 2015). According to Table 1, the redox gradient of anode and cathode were arranged as follows: GAC-CW-MFC $\triangle W H-C W-M F C \triangle$ CER-CW-MFC\IP-CW-MFC $\llbracket C W \llbracket N P-C W-M F C$. Therefore, GAC had more advantages over ceramsite to maintain a higher redox gradient. The presence of plants exhibited a positive effect on the redox gradient of CW-MFC, which was consistent with the previous report (Teoh et al. 2020). This was mainly a result of the increased surface availability of the microorganism biofilm and the release of oxygen to the rhizosphere through photosynthesis by the wetland plants (Di et al. 2020). Notably, Water hyacinth was superior to Iris pseudacorus in enhancing the redox gradient. It might be that the immoderate elongation caused by Iris pseudacorus roots destroyed the anaerobic environment and resulted in the high anode ORP (Liu et al. 2014).

Table $1 \mathrm{pH}$ and ORP of different CW-MFC system.

\begin{tabular}{|lclllll|}
\hline Parameters & CW & $\begin{array}{l}\text { NP-CW- } \\
\text { MFC }\end{array}$ & $\begin{array}{l}\text { GAC-CW- } \\
\text { MFC }\end{array}$ & $\begin{array}{l}\text { CER-CW- } \\
\text { MFC }\end{array}$ & $\begin{array}{l}\text { WH-CW- } \\
\text { MFC }\end{array}$ & $\begin{array}{l}\text { IP-CW- } \\
\text { MFC }\end{array}$ \\
\hline Anode pH & 6.88 & 6.84 & 6.70 & 7.08 & 6.92 & 6.83 \\
\hline Anode ORP $(\mathrm{mV})$ & -125 & -132 & -254 & -221 & -205 & -152 \\
\hline $\begin{array}{l}\text { Cathode ORP } \\
\text { (mV) }\end{array}$ & 102 & 93 & 128 & 105 & 151 & 143 \\
\hline $\begin{array}{l}\text { ORP gradient } \\
(\mathrm{mV})\end{array}$ & 227 & 225 & 382 & 326 & 356 & 295 \\
\hline
\end{tabular}

Note: CW: traditional constructed wetland; NP-CW-MFC: CW-MFC without any plant materials; GAC-CWMFC: CW-MFC filled with granular activated carbon in the anode layer; CER-CW-MFC: CW-MFC filled with ceramsite in the anode layer; WH-CW-MFC: CW-MFC planted with Water hyacinth in the sludge layer; IPCW-MFC: CW-MFC planted with Iris pseudacorus in the sludge layer.

\subsection{Bioelectricity generation of CW-MFCs}

\subsubsection{Output voltage}

The real-time output voltage and the maximum voltage of CW-MFC systems operated in the closed-circuit mode were monitored during the experiment period. As evident in Fig. 1, the output voltage of each system presented an obvious cyclical trend from increase to decrease during the first 40 days with the injection of nutrient solution. This might be attributed to the increased nutrient requirements of the electricigens caused by the nutrient solution, which was conducive to the system productivity. When the experiment entered the later period, the output voltage was basically stable due to the stability of CWMFC systems.

GAC-CW-MFC produced a maximum voltage of $534.30 \mathrm{mV}$, which was about $70.62 \%$ higher than that of assay CER-CW-MFC (Table 2). Ceramsite had been reported to inhibit the growth of electrochemically 
active bacteria as a result of its high iron content (Zhong et al. 2020). In contrast, the high conductivity of GAC made it more conducive to electron transfer, thereby exhibiting better electrical properties. Therefore, GAC might be more suitable for the growth of exoelectrogens in comparison to the ceramsite. The maximum voltages of NP-CW-MFC, WH-CW-MFC and IP-CW-MFC were 155.40, 537.64 and $250.52 \mathrm{mV}$, respectively. Obviously, the presence of plants, especially for water hyacinth, was conductive to boosting the power generation. A CW-MFC study of Acorus calamus was reported to produce a relatively low voltage and root exudation rate, and its exudation components had a significant impact on the distribution of microbial colonies in the system (Liu et al. 2020a). Thus, it might be speculated that the root effect of water hyacinth in CW-MFC could provide more organic matter for the growth of electrochemically active bacteria as compared to Iris pseudacorus.

Table 2 The power generation performance of different CW-MFC systems.

\begin{tabular}{|llll|}
\hline Systems & $\begin{array}{l}\text { Maximum voltage } \\
(\mathrm{mV})\end{array}$ & $\begin{array}{l}\text { Internal resistance } \\
(\Omega)\end{array}$ & $\begin{array}{l}\text { Maximal power density } \\
\left(\mathrm{mW} \cdot \mathrm{m}^{-3}\right)\end{array}$ \\
\hline NP-CW-MFC & 155.40 & 683.58 & 0.86 \\
\hline GAC-CW-MFC & 534.30 & 587.98 & 70.86 \\
\hline CER-CW-MFC & 313.21 & 787.90 & 16.66 \\
\hline WH-CW-MFC & 537.64 & 533.85 & 27.91 \\
\hline IP-CW-MFC & 250.52 & 583.43 & 9.88 \\
\hline
\end{tabular}

\subsubsection{Polarization curves and internal resistance analysis}

During the stable operation period, the power density and polarization curves of CW-MFCs were measured (Fig. 2). The results indicated that the power output differed markedly by the addition of substrates and plants among the five systems. Especially, the systems NP-CW-MFC, GAC-CW-MFC, CER-CW-MFC, WHCW-MFC and IP-CW-MFC reached the maximal power densities of $0.86,70.86,16.66,27.91$ and 9.88 $\mathrm{mW} \cdot \mathrm{m}^{-3}$, respectively (Table 2). Polarization curves provided valuable information about the activation, ohmic and concentration losses which adversely affect the electrogenesis capacity of MFC (Logan et al., 2006)(Logan et al. 2006, Srivastava et al. 2015). In this experiment, the polarization curve of CW-MFC with approximate linearity was mainly the ohmic polarization region. The output voltage and polarization curve decreased linearly with the increase of current density. As a consequence, the apparent internal resistance of MFCs could be calculated according to the slope of the polarization curve (Table 2).

The system CER-CW-MFC had the highest internal resistance $(787.9 \Omega)$, followed by NP-CW-MFC (683.58 $\Omega)$, GAC-CW-MFC (587.98 $\Omega)$, IP-CW-MFC (583.43 $\Omega$ ) and WH-CW-MFC (533.85 $\Omega)$. Thus, ceramsite employed as the substrate strongly enhanced the system internal resistance. On the contrary, the cultivation of plants played an important role in reducing the internal resistance. This effect was attributed to the fact that plants could increase the number of cathode microorganisms and accelerate 
the oxygen reduction reaction, thereby reducing the internal resistance (Fang et al. 2013). Little difference in internal resistance of systems WH-CW-MFC and IP-CW-MFC was noted, whereas the maximum voltage and power density varied remarkably. This might related to the differences of redox gradient caused by oxygen transfer and anaerobic environment destruction in the roots of two wetland plants (Liu et al. 2014). In conclusion, the root depth and distribution of wetland plants was imperative to be considered to avoid the breakdown of CW-MFC system (Helder et al. 2010).

\subsection{Heavy metal removal from sludge}

In order to investigate the effect of substrate and plant types on the removal of $\mathrm{Zn}$ and Ni from sludge, cathode sludge samples from six CW-MFC systems were collected after a two-month operation period. As viewed in Fig. 3, almost more than 50\% removal of $\mathrm{Zn}$ and Ni were obtained in six systems. GAC-CW-MFC produced the maximum $\mathrm{Zn}$ and $\mathrm{Ni}$ removal efficiencies of $76.88 \%$ and $66.02 \%$, which were respectively about $25 \%$ and $7 \%$ higher than that of CW. The micro-electrolysis formed by CW-MFC system and the root exudates produced by plants were found to stimulate the activity and growth of microorganisms and wetland plants causing enhanced pollutant removal (Wang et al. 2017). Thus, the CW-MFC in closed circuit performed superior to that in open circuit (CW) with respect to $\mathrm{Zn}$ and Ni removal from sludge.

Upper Zn and Ni removal rates were achieved in GAC-CW-MFC device as compared to CER-CW-MFC, indicating that GAC enhanced heavy metal removal seriously. Carbonaceous materials, such as activated carbon and graphite granules, had been proven to possess the large specific surface area for the adhesion and growth of microbes (Fang et al. 2017). Meanwhile, its good electrical conductivity also contributed to the heavy metal removal performance by facilitating the cathode microbial activity. $60.93 \%$ and $55.91 \%$ removal of Zn and Ni were obtained in system NP-CW-MFC, respectively, which were lower than those in WH-CW-MFC but higher than those in IP-CW-MFC (seen in Fig. 3). It indicated that the heavy metal removal by CW-MFCs differed remarkably as a result of adding different types of wetland plants. Among these, Water hyacinth displayed a positive effect due to its high absorption capacity of heavy metals and the catalysis on microbial metabolism (Saz et al. 2018).

\subsection{Migration and transformation of heavy metals}

\subsubsection{Migration of $\mathrm{Zn}$ and $\mathrm{Ni}$}

As shown in Table 3, the enrichment capacity of $\mathrm{Zn}$ and $\mathrm{Ni}$ in roots of each system was stronger than that in stems and leaves. It was speculated that heavy metals could be directly absorbed by the roots immersed in the sludge, whereas needed to be transported to the stems and leaves. The enrichment rates of $\mathrm{Zn}$ and Ni reached $13.75 \%$ and $11.95 \%$ for CW, $29.8 \%$ and $19.59 \%$ for GAC-CW-MFC, $13.76 \%$ and $12.04 \%$ for CER-CW-MFC, respectively. Obviously, the integration of a MFC could enhance the enrichment of $\mathrm{Zn}$ and $\mathrm{Ni}$ in CWs. Apparent differences in the enrichment of heavy metals in presence of different wetland plants were also noted. The plant biomass of GAC-CW-MFC was approximately 0.03 and $0.04 \mathrm{~g}$ higher than that of CW and CER-CW-MFC, respectively. On one hand, micro-current environment was beneficial to the growth of plants to some extent (Zhou et al. 2018). On the other, more biomass 
production in CW-MFCs could generate more bioelectricity and improve the aerobic microbial activity, thereby facilitating the pollutant removal (Di et al. 2020). The enrichment of heavy metals in system WHCW-MFC was much higher than that in IP-CW-MFC, while the biomass presented the opposite results. This abnormal phenomenon might be owing to the fact that Iris pseudacorus rooted beneath the sludge layer during the experiment, which greatly reduced its absorption and metabolism of $\mathrm{Zn}$ and Ni from sludge. Hence, the wetland plant Water hyacinth with good anti-sludge performance could be considered as candidate against potential toxic effects of sludge.

Table 3 The enrichment of heavy metals by plants in each system.

\begin{tabular}{|c|c|c|c|c|c|c|c|}
\hline \multirow[t]{2}{*}{ Systems } & \multicolumn{2}{|c|}{ Dry weight (g) } & \multirow{2}{*}{$\begin{array}{l}\text { Heavy } \\
\text { metal }\end{array}$} & \multicolumn{2}{|c|}{ Content $\left(\mathrm{mg} \cdot \mathrm{kg}^{-1}\right)$} & \multicolumn{2}{|c|}{ Enrichment rate (\%) } \\
\hline & Roots & $\begin{array}{l}\text { Stems and } \\
\text { leaves }\end{array}$ & & Roots & $\begin{array}{l}\text { Stems and } \\
\text { leaves }\end{array}$ & Roots & $\begin{array}{l}\text { Stems } \\
\text { and } \\
\text { leaves }\end{array}$ \\
\hline \multirow[t]{2}{*}{ CW } & \multirow[t]{2}{*}{0.2136} & \multirow[t]{2}{*}{0.5274} & $\mathrm{Zn}$ & 750.00 & 364.00 & 9.26 & 4.49 \\
\hline & & & $\mathrm{Ni}$ & 355.33 & 122.71 & 8.88 & 3.07 \\
\hline \multirow{2}{*}{$\begin{array}{l}\text { GAC-CW- } \\
\text { MFC }\end{array}$} & \multirow[t]{2}{*}{0.2284} & \multirow[t]{2}{*}{0.5457} & $\mathrm{Zn}$ & 1790.00 & 623.90 & 22.10 & 7.70 \\
\hline & & & $\mathrm{Ni}$ & 579.28 & 204.50 & 14.48 & 5.11 \\
\hline \multirow{2}{*}{$\begin{array}{l}\text { CER-CW- } \\
\text { MFC }\end{array}$} & \multirow[t]{2}{*}{0.2156} & \multirow[t]{2}{*}{0.5198} & $\mathrm{Zn}$ & 871.00 & 243.62 & 10.75 & 3.01 \\
\hline & & & $\mathrm{Ni}$ & 360.02 & 121.40 & 9.00 & 3.04 \\
\hline \multirow{2}{*}{$\begin{array}{l}\text { WH-CW- } \\
\text { MFC }\end{array}$} & \multirow[t]{2}{*}{0.2398} & \multirow[t]{2}{*}{0.5546} & $\mathrm{Zn}$ & 1709.50 & 615.32 & 21.10 & 7.60 \\
\hline & & & $\mathrm{Ni}$ & 546.00 & 199.20 & 13.65 & 4.98 \\
\hline \multirow{2}{*}{$\begin{array}{l}\text { IP-CW- } \\
\text { MFC }\end{array}$} & \multirow[t]{2}{*}{1.6207} & \multirow[t]{2}{*}{1.7588} & $\mathrm{Zn}$ & 832.10 & 221.12 & 10.27 & 2.73 \\
\hline & & & $\mathrm{Ni}$ & 390.40 & 142.44 & 9.76 & 3.56 \\
\hline
\end{tabular}

Heavy metals ( $\mathrm{Zn}$ and $\mathrm{Ni}$ ) were enriched not only by the plants, but also near the cathode to achieve the removal. The enrichment properties of $\mathrm{Zn}$ and Ni for each system cathode were presented in Fig. 4. GACCW-MFC cathode showed the highest enrichment rates of $\mathrm{Zn}$ and $\mathrm{Ni}(27.16 \%$ and $15.13 \%$, respectively) in comparison with NP-CW-MFC and CER-CW-MFC cathode. This confirmed that the heavy metal removal in CW-MFCs occurred more readily by GAC addition than by the ceramsite. Additionally, water hyacinthe contributed more to the enrichment of $\mathrm{Zn}$ and $\mathrm{Ni}$ on the cathode as compared to Iris pseudacorus.

\subsubsection{Chemical form transformation of $\mathrm{Zn}$ and $\mathrm{Ni}$}

As presented in Fig. 5, the main peaks observed at 285 and $531 \mathrm{eV}$ corresponded to the $\mathrm{C} 1 \mathrm{~s}$ and $01 \mathrm{~s}$ bands, respectively. Simultaneously, the addition peaks detectable at 853 and $1022 \mathrm{eV}$ were attributed to $\mathrm{Ni} 2 \mathrm{p}$ and $\mathrm{Zn} 2 \mathrm{p}$. C1s was caused by exposure to the small molecules in $\mathrm{CO}_{2}$, air and water. The high 
peak position (531 eV) of 01s was attributed to the high oxygen content of sludge at the system cathode, and classified as the peak of chemisorbed oxygen on the surface (Ahmed et al. 2013).

$\mathrm{Zn} 2 \mathrm{p}$ and Ni2p spectrograms of the sludge treated by different substrates and plants were displayed in Fig. 6 . The $Z n 2 p 3 / 2$ peaks were relatively sharp and exhibited at binding energy characteristic (i.e. $1021.3 \mathrm{eV}$ and $1021.7 \mathrm{eV}$ ) of $\mathrm{Zn}$ and $\mathrm{Zn}^{2+}$ (Blumentrit et al. 2011, Wu et al. 2017). The binding energy of $\mathrm{Zn} 2 \mathrm{p} 1 / 2$ was located at $1045.0 \mathrm{eV}$. These results indicated that $\mathrm{Zn}$ mainly combined with oxygen in the form of $\mathrm{Zn}^{2+}$, namely $\mathrm{ZnO}$ (Morozov et al. 2015). Six separated peaks at 853.4, 855.3, 856.342, 872.4, 872.6 and $873.6 \mathrm{eV}$ were observed for metallic $\mathrm{Ni}(2 \mathrm{p} 3 / 2), \mathrm{NiO}(2 \mathrm{p} 3 / 2), \mathrm{Ni}(\mathrm{OH})_{2}(2 \mathrm{p} 3 / 2)$, metallic $\mathrm{Ni}$ $(2 \mathrm{p} 1 / 2), \mathrm{NiO}(2 \mathrm{p} 1 / 2)$ and $\mathrm{Ni}(\mathrm{OH})_{2}(2 \mathrm{p} 1 / 2)$, respectively (Pattanayak et al. 2019, Vivet et al. 2020). After a 60-day operation period, the satellite peaks of Zn2p and Ni2p became smaller, especially in systems GACCW-MFC and WH-CW-MFC, indicating that the high-valence $\mathrm{Zn}$ and Ni were continuously reduced to lowvalence or elemental substances (Liu et al. 2015).

The peak positions of Zn2p and Ni2p had scarcely any displacement during the operation. The binding energies of Zn2p and Ni2p shifted slightly to the direction of higher ones accompanied by optimizing the substrate and plant types. The $\mathrm{Zn}$ and Ni contents on the sludge surface decreased due to their formation of metal oxides (Sheng et al. 2011). In summary, the obtained XPS results would provide evidences in proving the reduction and removal of metal ions on the cathode by gaining the electronics (Liu et al. 2019).

\section{Conclusions}

The impacts of different substrates and plants towards the heavy metal ( $\mathrm{Zn}$ and $\mathrm{Ni}$ ) treatment of sludge as well as electricity generation in CW-MFCs were evaluated. Among these, GAC and Water hyacinth was respectively the most effective promoter. In the corresponding CW-MFCs, plant roots and electrodes were confirmed to play major roles in the migration of $\mathrm{Zn}$ and $\mathrm{Ni}$. The main heavy metals on the sludge surface were analyzed as $\mathrm{Zn}$ and Ni. Besides, the high-valence $\mathrm{Zn}$ and Ni were effectively reduced to low-valence or elemental metals. Our findings provide a theoretical guidance for the resource utilization of municipal sludge. Besides, the CW-MFC signifies its potential application prospects in the removal of heavy metals from sludge.

\section{Declarations}

\section{Ethics approval and consent to participate}

Not applicable.

\section{Consent for publication}

Not applicable. 
Availability of data and materials

Not applicable.

\section{Competing interests}

The authors declare that they have no competing interests.

\section{Funding}

This study was supported by the Key Research and Development Program of Anhui Provincial Science Technology Department (201904a07020083), the Key Program of Anhui Polytechnic University (Xjky2020086) and the Anhui Polytechnic University "Young and Middle-Aged Top Talent" Training Program.

\section{Authors' contributions}

DX formulated overarching research goals and aims. LW and TL performed material preparation, data collection and analysis. The first draft of the manuscript was written by LW. Revision was charged by QZ and ZT. All authors commented on previous versions of the manuscript. All authors read and approved the final manuscript.

\section{Acknowledgements}

The authors acknowledge the financial support by the Key Research and Development Program of Anhui Provincial Science Technology Department (201904a07020083), the Key Program of Anhui Polytechnic University (Xjky2020086) and the Anhui Polytechnic University "Young and Middle-Aged Top Talent" Training Program .

\section{References}

1. Ahmed MH, Byrne JA, McLaughlin J, Ahmed W (2013) Study of Human Serum Albumin Adsorption and Conformational Change on DLC and Silicon Doped DLC Using XPS and FTIR Spectroscopy. Journal of Biomaterials and Nanobiotechnology 04(02):194-203. https://doi.org/10.4236/jbnb.2013.42024

2. Blumentrit $P$, Yoshitake M, Nemšák $S$, Kim T, Nagata T (2011) XPS and UPS study on band alignment at Pt-Zn-terminated ZnO(0001) interface. Applied Surface Science 258(2):780-785. https://doi.org/10.1016/j.apsusc.2011.08.095

3. Chen SY, Cheng YK (2019) Effects of sulfur dosage and inoculum size on pilot-scale thermophilic bioleaching of heavy metals from sewage sludge. Chemosphere 234:346-355. https://doi.org/10.1016/j.chemosphere.2019.06.084

4. Di L, Li Y, Nie L, Wang S, Kong F (2020) Influence of plant radial oxygen loss in constructed wetland combined with microbial fuel cell on nitrobenzene removal from aqueous solution. J Hazard Mater 
394:122542. https://doi.org/10.1016/j.jhazmat.2020.122542

5. Doherty L, Zhao Y, Zhao X, Hu Y, Hao X, Xu L, Liu R (2015) A review of a recently emerged technology: Constructed wetland-Microbial fuel cells. Water Res 85:38-45. https://doi.org/10.1016/j.watres.2015.08.016

6. Fan J, Zhang B, Zhang J, Ngo HH, Guo W, Liu F, Guo Y, Wu H (2013) Intermittent aeration strategy to enhance organics and nitrogen removal in subsurface flow constructed wetlands. Bioresour Technol 141:117-22. https://doi.org/10.1016/j.biortech.2013.03.077

7. Fang Z, Song HL, Cang N, Li XN (2013) Performance of microbial fuel cell coupled constructed wetland system for decolorization of azo dye and bioelectricity generation. Bioresour Technol 144:165-71. https://doi.org/10.1016/j.biortech.2013.06.073

8. Fang Z, Cheng S, Wang H, Cao X, Li X (2017) Feasibility study of simultaneous azo dye decolorization and bioelectricity generation by microbial fuel cell-coupled constructed wetland: substrate effects. RSC Advances 7(27):16542-16552. https://doi.org/10.1039/c7ra01255a

9. Gao J, Luo Q, Zhang C, Li B, Meng L (2013) Enhanced electrokinetic removal of cadmium from sludge using a coupled catholyte circulation system with multilayer of anion exchange resin. Chemical Engineering Journal 234:1-8. https://doi.org/10.1016/j.cej.2013.08.019

10. Ge X, Cao X, Song X, Wang Y, Si Z, Zhao Y, Wang W, Tesfahunegn AA (2020) Bioenergy generation and simultaneous nitrate and phosphorus removal in a pyrite-based constructed wetland-microbial fuel cell. Bioresour Technol 296:122350. https://doi.org/10.1016/j.biortech.2019.122350

11. Gupta S, Srivastava P, Patil SA, Yadav AK (2021) A comprehensive review on emerging constructed wetland coupled microbial fuel cell technology: Potential applications and challenges. Bioresour Technol 320(Pt B):124376. https://doi.org/10.1016/j.biortech.2020.124376

12. Helder M, Strik DP, Hamelers HV, Kuhn AJ, Blok C, Buisman CJ (2010) Concurrent bio-electricity and biomass production in three Plant-Microbial Fuel Cells using Spartina anglica, Arundinella anomala and Arundo donax. Bioresour Technol 101(10):3541-7.

https://doi.org/10.1016/j.biortech.2009.12.124

13. Hu S, Hu J, Sun Y, Zhu Q, Wu L, Liu B, Xiao K, Liang S, Yang J, Hou H (2021) Simultaneous heavy metal removal and sludge deep dewatering with $\mathrm{Fe}(\mathrm{II})$ assisted electrooxidation technology. J Hazard Mater 405:124072. https://doi.org/10.1016/j.jhazmat.2020.124072

14. Ke X, Zhang G, Wan T, Gao F (2012) Heavy-Metal Accumulation in Low-Sludge Wastewater Treatment Technique: Sonication-Cryptic Growth. Journal of Environmental Engineering 138(3):248251. https://doi.org/10.1061/(asce)ee.1943-7870.0000418

15. Li M, Zhou S, Xu Y, Liu Z, Ma F, Zhi L, Zhou X (2018) Simultaneous $\operatorname{Cr}(V I)$ reduction and bioelectricity generation in a dual chamber microbial fuel cell. Chemical Engineering Journal 334:1621-1629. https://doi.org/10.1016/j.cej.2017.11.144

16. Liu F, Sun L, Wan J, Shen L, Yu Y, Hu L, Zhou Y (2020a) Performance of different macrophytes in the decontamination of and electricity generation from swine wastewater via an integrated constructed 
wetland-microbial fuel cell process. J Environ Sci (China) 89:252-263. https://doi.org/10.1016/j.jes.2019.08.015

17. Liu S, Song H, Wei S, Yang F, Li X (2014) Bio-cathode materials evaluation and configuration optimization for power output of vertical subsurface flow constructed wetland - microbial fuel cell systems. Bioresour Technol 166:575-83. https://doi.org/10.1016/j.biortech.2014.05.104

18. Liu T, Liu Z, Zheng Q, Lang Q, Xia Y, Peng N, Gai C (2018a) Effect of hydrothermal carbonization on migration and environmental risk of heavy metals in sewage sludge during pyrolysis. Bioresour Technol 247:282-290. https://doi.org/10.1016/j.biortech.2017.09.090

19. Liu T, Xu D, Wang L, Yang W, Xia Y (2020b) Effect of electrode spacing on the removal of Zn and Ni in sludge and its electricity generation performance by CW-MFC. Chemical Industry and Engineering Progress:1-13. https://doi.org/10.16085/j.issn.1000-6613.2020-1665

20. Liu W, Zhang J, Jin Y, Zhao X, Cai Z (2015) Adsorption of Pb(II), Cd(II) and Zn(II) by extracellular polymeric substances extracted from aerobic granular sludge: Efficiency of protein. Journal of Environmental Chemical Engineering 3(2):1223-1232. https://doi.org/10.1016/j.jece.2015.04.009

21. Liu W, Zheng J, Ou X, Liu X, Song Y, Tian C, Rong W, Shi Z, Dang Z, Lin Z (2018b) Effective Extraction of $\mathrm{Cr}(\mathrm{VI})$ from Hazardous Gypsum Sludge via Controlling the Phase Transformation and Chromium Species. Environ Sci Technol 52(22):13336-13342. https://doi.org/10.1021/acs.est.8b02213

22. Liu Y, Song P, Gai R, Yan C, Jiao Y, Yin D, Cai L, Zhang L (2019) Recovering platinum from wastewater by charring biofilm of microbial fuel cells (MFCs). Journal of Saudi Chemical Society 23(3):338-345. https://doi.org/10.1016/j.jscs.2018.08.003

23. Logan BE, Hamelers B, Rozendal R, Schröder U, Keller J, Freguia S, Aelterman P, Verstraete W, Rabaey K (2006) Microbial fuel cells: methodology and technology. Environmental science \& technology 40(17):5181-5192. https://doi.org/10.1021/es0605016

24. Meng D, Wu J, Xu Z, Xu Y, Li H, Jin W, Zhang J (2020) Effect of passive ventilation on the performance of unplanted sludge treatment wetlands: heavy metal removal and microbial community variation. Environ Sci Pollut Res Int 27(25):31665-31676. https://doi.org/10.1007/s11356-020-09288-w

25. Morozov IG, Belousova OV, Ortega D, Mafina MK, Kuznetcov MV (2015) Structural, optical, XPS and magnetic properties of $\mathrm{Zn}$ particles capped by $\mathrm{ZnO}$ nanoparticles. Journal of Alloys and Compounds 633:237-245. https://doi.org/10.1016/j.jallcom.2015.01.285

26. Mu C, Wang L, Wang L (2020) Performance of lab-scale microbial fuel cell coupled with unplanted constructed wetland for hexavalent chromium removal and electricity production. Environ Sci Pollut Res Int 27(20):25140-25148. https://doi.org/10.1007/s11356-020-08982-z

27. Pattanayak P, Papiya F, kumar V, Pramanik N, Kundu PP (2019) Deposition of Ni-NiO nanoparticles on the reduced graphene oxide filled polypyrrole: evaluation as cathode catalyst in microbial fuel cells. Sustainable Energy \& Fuels 3(7):1808-1826. https://doi.org/10.1039/c9se00055k

28. Qian L, Wang S, Xu D, Guo Y, Tang X, Wang L (2016) Treatment of municipal sewage sludge in supercritical water: A review. Water Res 89:118-31. https://doi.org/10.1016/j.watres.2015.11.047 
29. Saz C, Ture C, Turker OC, Yakar A (2018) Effect of vegetation type on treatment performance and bioelectric production of constructed wetland modules combined with microbial fuel cell (CW-MFC) treating synthetic wastewater. Environ Sci Pollut Res Int 25(9):8777-8792. https://doi.org/10.1007/s11356-018-1208-y

30. Shamsollahi HR, Alimohammadi M, Momeni S, Naddafi K, Nabizadeh R, Khorasgani FC, Masinaei M, Yousefi M (2019) Assessment of the Health Risk Induced by Accumulated Heavy Metals from Anaerobic Digestion of Biological Sludge of the Lettuce. Biol Trace Elem Res 188(2):514-520. https://doi.org/10.1007/s12011-018-1422-y

31. Shen X, Zhang J, Liu D, Hu Z, Liu H (2018) Enhance performance of microbial fuel cell coupled surface flow constructed wetland by using submerged plants and enclosed anodes. Chemical Engineering Journal 351:312-318. https://doi.org/10.1016/j.cej.2018.06.117

32. Sheng G, Yang S, Sheng J, Hu J, Tan X, Wang X (2011) Macroscopic and microscopic investigation of $\mathrm{Ni}(\mathrm{II})$ sequestration on diatomite by batch, XPS, and EXAFS techniques. Environ Sci Technol 45(18):7718-26. https://doi.org/10.1021/es202108q

33. Srivastava P, Yadav AK, Mishra BK (2015) The effects of microbial fuel cell integration into constructed wetland on the performance of constructed wetland. Bioresour Technol 195:223-30. https://doi.org/10.1016/j.biortech.2015.05.072

34. Srivastava P, Dwivedi S, Kumar N, Abbassi R, Garaniya V, Yadav AK (2017) Performance assessment of aeration and radial oxygen loss assisted cathode based integrated constructed wetland-microbial fuel cell systems. Bioresour Technol 244(Pt 1):1178-1182.

https://doi.org/10.1016/j.biortech.2017.08.026

35. Teoh T-P, Ong S-A, Ho L-N, Wong Y-S, Oon Y-L, Oon Y-S, Tan S-M, Thung W-E (2020) Up-flow constructed wetland-microbial fuel cell: Influence of floating plant, aeration and circuit connection on wastewater treatment performance and bioelectricity generation. Journal of Water Process Engineering 36:101371. https://doi.org/10.1016/j.jwpe.2020.101371

36. Vivet L, Benoit R, Falzon MF, Tan KL, Dorairaj D, Morelle JM (2020) XPS, ToF SIMS and wettability analyses on Ni surfaces after Ar-H2 RF plasma treatment: An efficient and optimized plasma treatment approach. Surface and Coatings Technology 398:126094. https://doi.org/10.1016/j.surfcoat.2020.126094

37. Wang J, Song X, Wang Y, Bai J, Bai H, Yan D, Cao Y, Li Y, Yu Z, Dong G (2017) Bioelectricity generation, contaminant removal and bacterial community distribution as affected by substrate material size and aquatic macrophyte in constructed wetland-microbial fuel cell. Bioresour Technol 245(Pt A):372-378. https://doi.org/10.1016/j.biortech.2017.08.191

38. Wang X, Tian Y, Liu H, Zhao X, Wu Q (2019) Effects of influent COD/TN ratio on nitrogen removal in integrated constructed wetland-microbial fuel cell systems. Bioresour Technol 271:492-495. https://doi.org/10.1016/j.biortech.2018.09.039

39. Wang Y, Cai Z, Sheng S, Pan F, Chen F, Fu J (2020) Comprehensive evaluation of substrate materials for contaminants removal in constructed wetlands. Sci Total Environ 701:134736. 
https://doi.org/10.1016/j.scitotenv.2019.134736

40. Wu Z-W, Tyan S-L, Chen H-H, Huang J-C-A, Huang Y-C, Lee C-R, Mo T-S (2017) Temperaturedependent photoluminescence and XPS study of $\mathrm{ZnO}$ nanowires grown on flexible $\mathrm{Zn}$ foil via thermal oxidation. Superlattices and Microstructures 107:38-43.

https://doi.org/10.1016/j.spmi.2017.04.016

41. Xu F, Ouyang DL, Rene ER, Ng HY, Guo LL, Zhu YJ, Zhou LL, Yuan Q, Miao MS, Wang Q, Kong Q (2019) Electricity production enhancement in a constructed wetland-microbial fuel cell system for treating saline wastewater. Bioresour Technol 288:121462. https://doi.org/10.1016/j.biortech.2019.121462

42. Xu H, Song HL, Singh RP, Yang YL, Xu JY, Yang XL (2021) Simultaneous reduction of antibiotics leakage and methane emission from constructed wetland by integrating microbial fuel cell. Bioresour Technol 320(Pt A):124285. https://doi.org/10.1016/j.biortech.2020.124285

43. Yang J, Zhao C, Xing M, Lin Y (2013) Enhancement stabilization of heavy metals ( $\mathrm{Zn}, \mathrm{Pb}, \mathrm{Cr}$ and $\mathrm{Cu}$ ) during vermifiltration of liquid-state sludge. Bioresour Technol 146:649-655. https://doi.org/10.1016/j.biortech.2013.07.144

44. Zhao C, Shang D, Zou Y, Du Y, Wang Q, Xu F, Ren L, Kong Q (2020) Changes in electricity production and microbial community evolution in constructed wetland-microbial fuel cell exposed to wastewater containing Pb(II). Sci Total Environ 732:139127. https://doi.org/10.1016/j.scitotenv.2020.139127

45. Zhong F, Yu C, Chen Y, Wu X, Wu J, Liu G, Zhang J, Deng Z, Cheng S (2020) Nutrient Removal Process and Cathodic Microbial Community Composition in Integrated Vertical-Flow Constructed Wetland Microbial Fuel Cells Filled With Different Substrates. Front Microbiol 11:1896. https://doi.org/10.3389/fmicb.2020.01896

46. Zhou G, Gu Y, Yuan H, Gong Y, Wu Y (2020) Selecting sustainable technologies for disposal of municipal sewage sludge using a multi-criterion decision-making method: A case study from China. Resources, Conservation and Recycling 161:104881. https://doi.org/10.1016/j.resconrec.2020.104881

47. Zhou Y, Xu D, Xiao E, Xu D, Xu P, Zhang X, Zhou Q, He F, Wu Z (2018) Relationship between electrogenic performance and physiological change of four wetland plants in constructed wetlandmicrobial fuel cells during non-growing seasons. J Environ Sci (China) 70:54-62. https://doi.org/10.1016/j.jes.2017.11.008

\section{Figures}




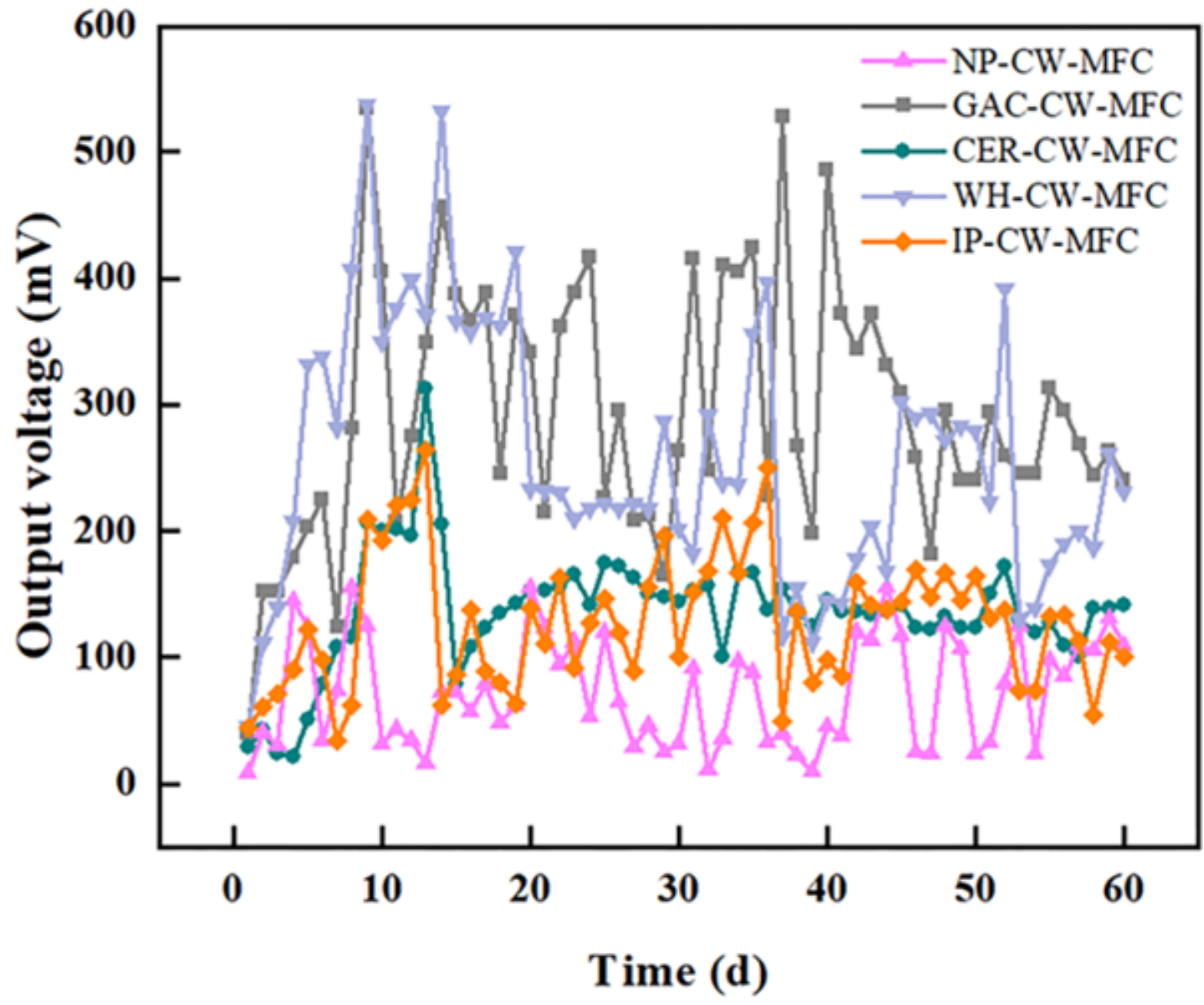

Figure 1

Output voltages of different CW-MFC systems.
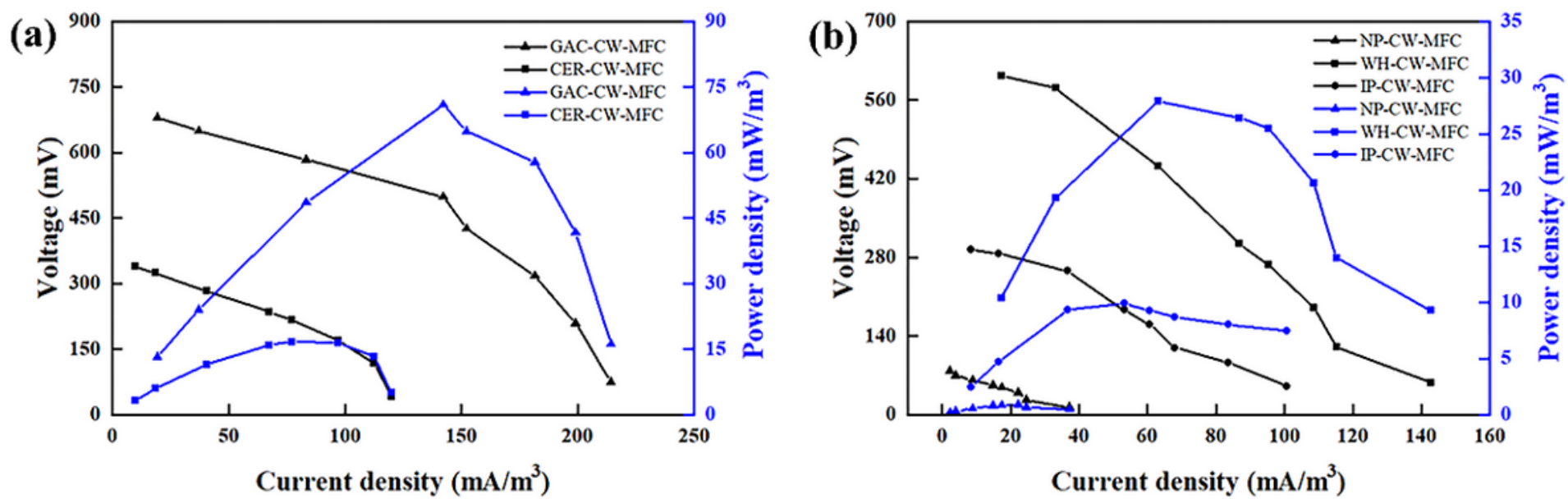

Figure 2

Polarization curves of different substrates (a) and wetland plants (b). 


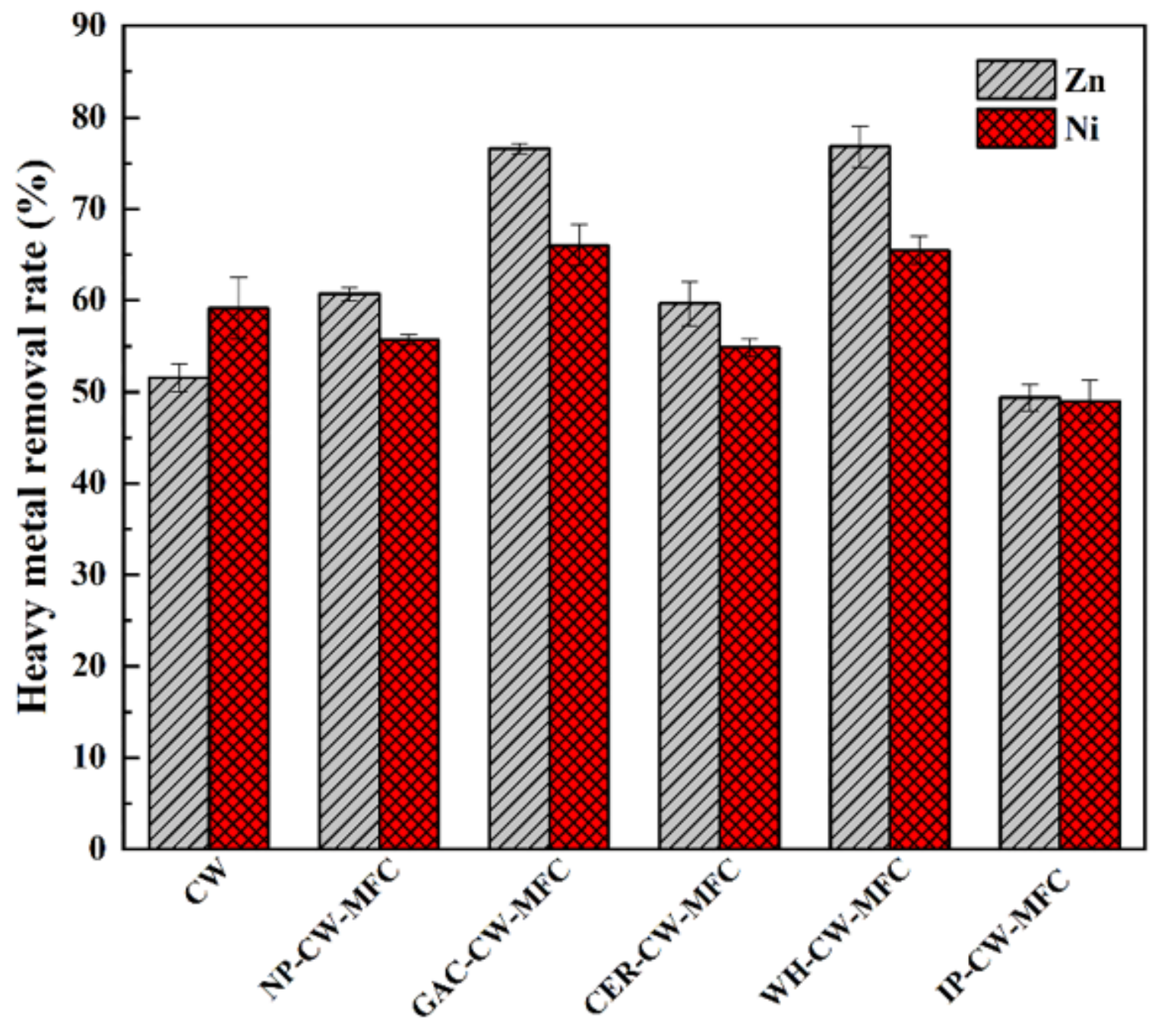

Figure 3

Effect of different substrates and wetland plants on the removal of $\mathrm{Zn}$ and Ni from sludge. Data were shown as Mean $\pm S E$ of 3 replicates. 


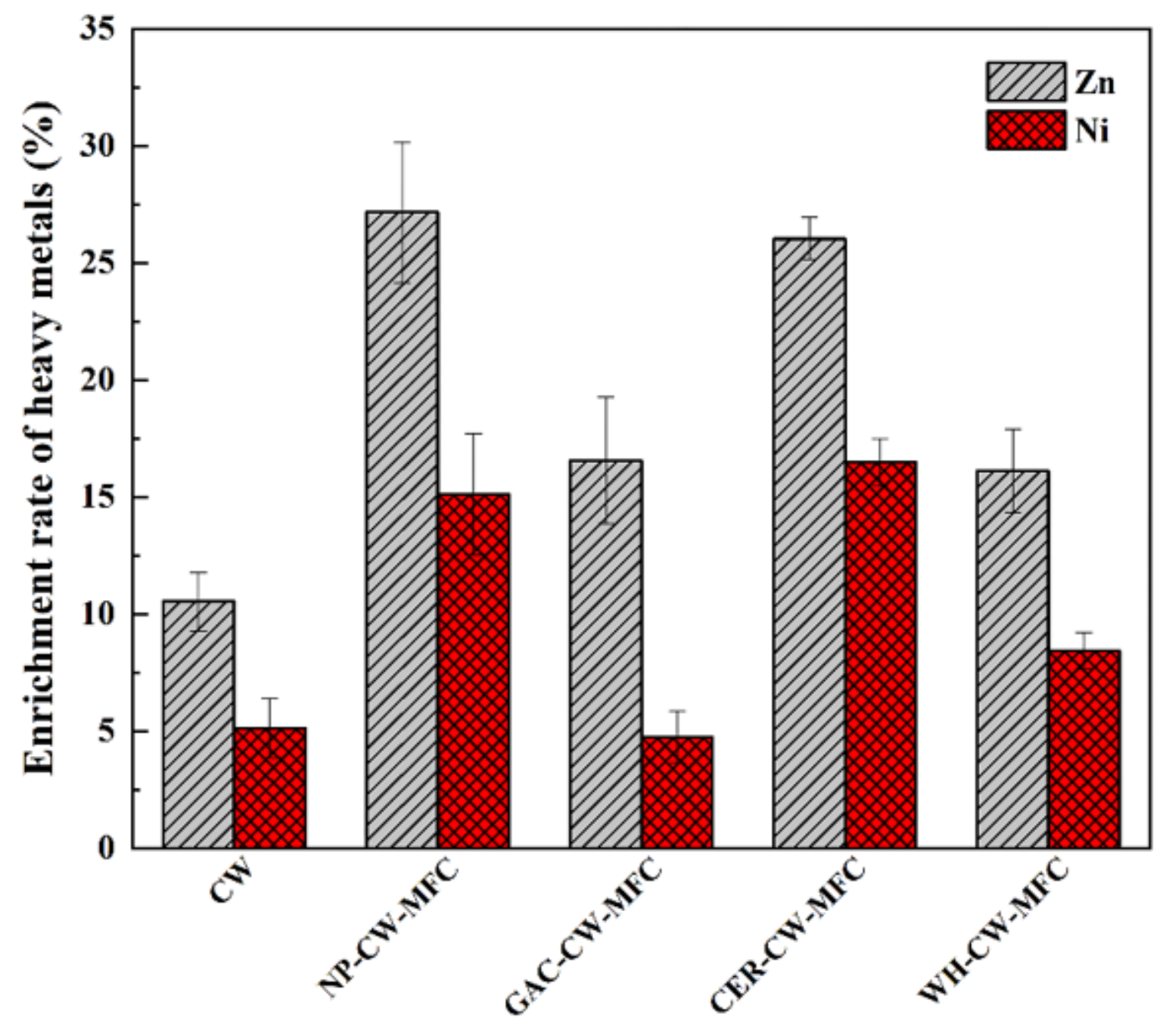

Figure 4

The enrichment rates of heavy metals in each system cathode. Data were shown as Mean $\pm S E$ of 3 replicates.
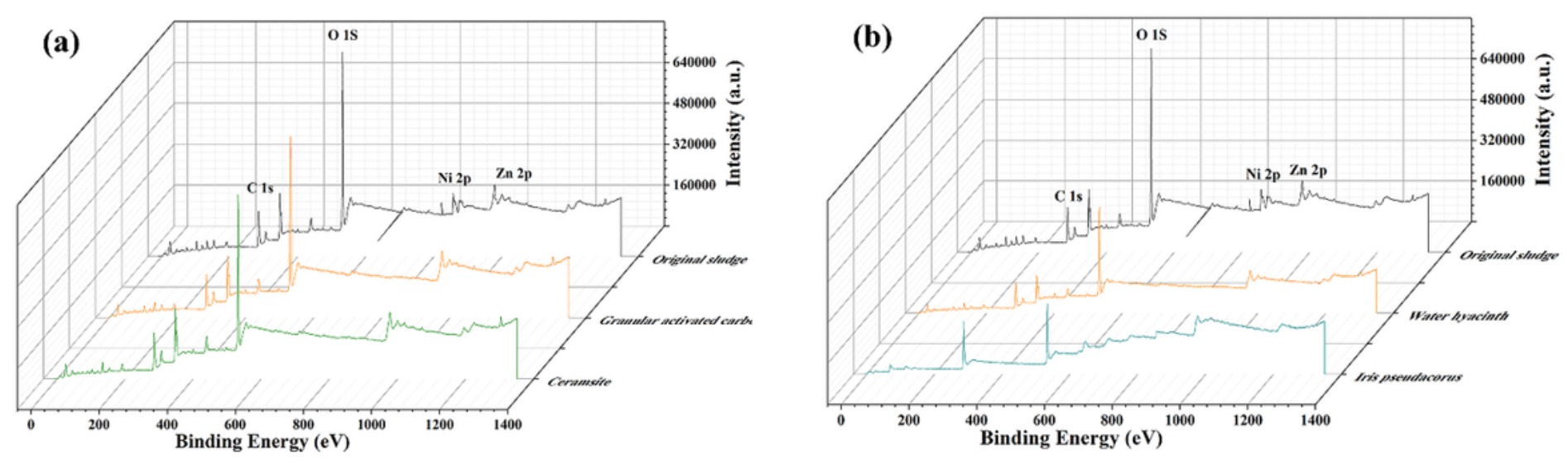

Figure 5

XPS full spectrum of the original sludge and the sludge treated by different substrates (a) and plants (b). 

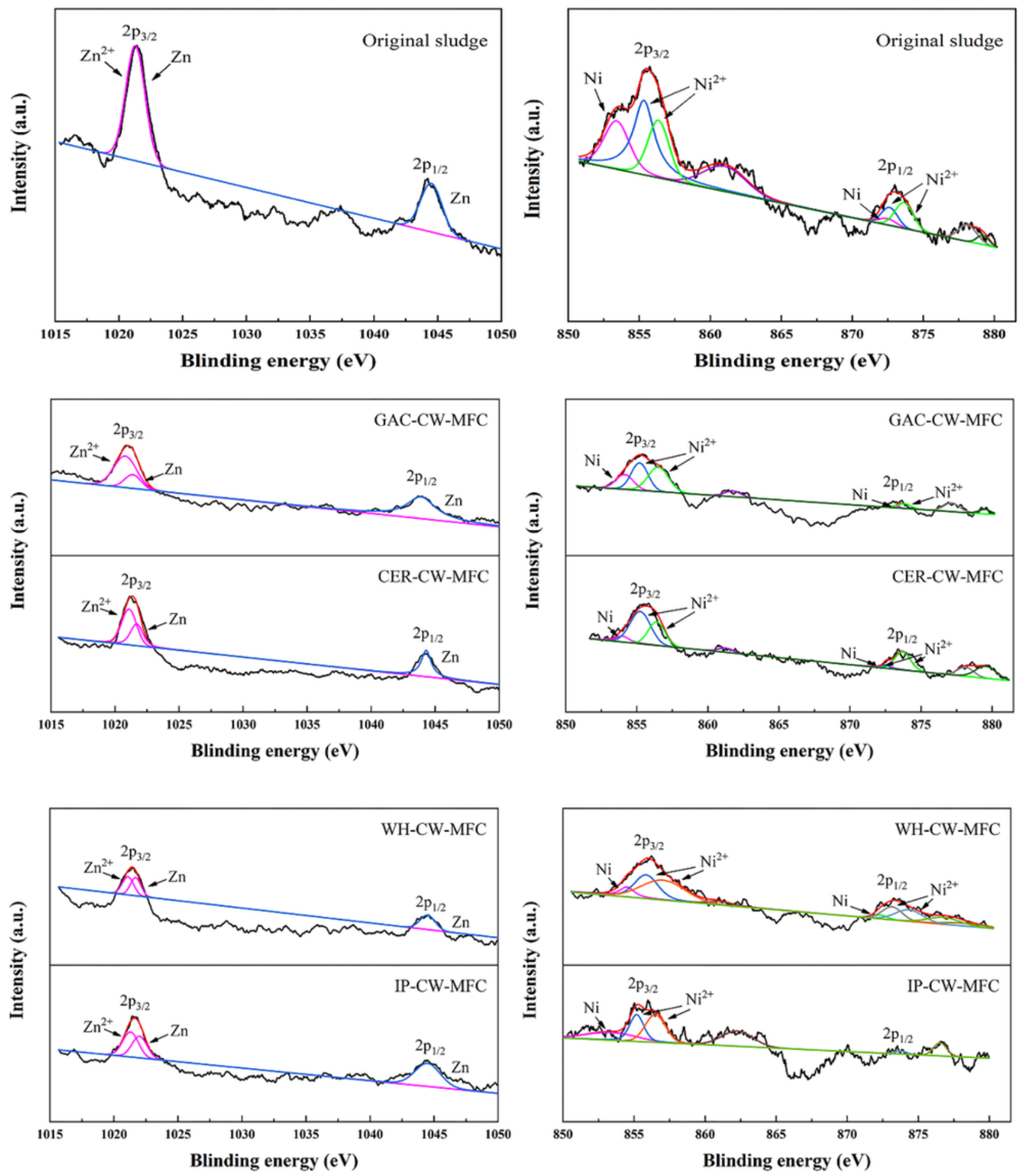

Figure 6

Zn2p and Ni2p spectrograms of the original sludge and the sludge treated by different systems. 